\title{
Analysis of human relations theory of management: A quest to re-enact people's management towards peace in university system
}

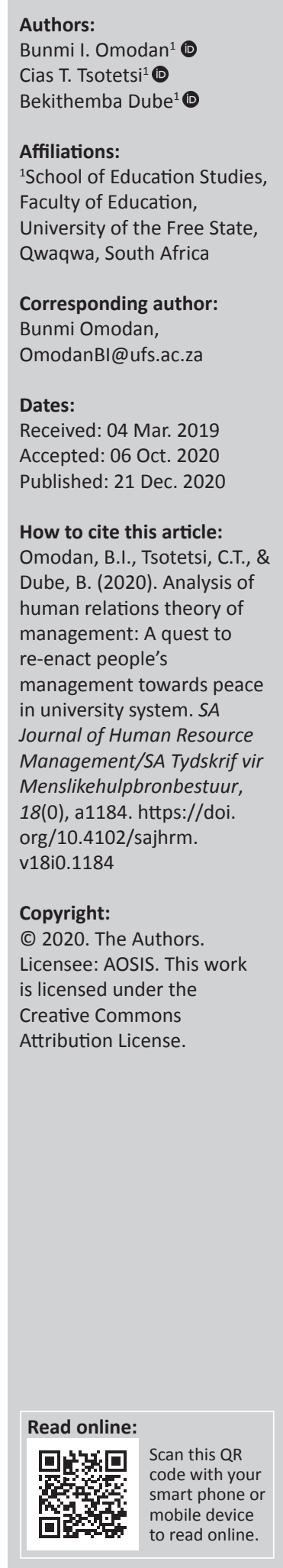

\begin{abstract}
Orientation Research Purpose: In response to social unrest that has eaten deep into the fabric of the University system in Nigeria, this theoretical paper is positioned to respond by examining the Human Relations Theory of Management (HRTM) as a suggestible solution to the management of the incessant students' oriented crisis in the system. The theory was argued towards exposing the dividends enjoy by organisational stakeholders emanating from the outcome of the Hawthorne study.
\end{abstract}

Research approach and Finding: The study adopted literature and observations as a research approach, while theoretical analysis was employed to interpret and make sense of HRTM. The analysis was considered from its evolutionary point of view; the development of Human Relation Theory of Management, the contributions of Jacob Moreno's stoichiometry and McGregor's Theory $X$ and Y. I further argued and justified that the assumptions of the theory such as; belongingness, inclusiveness and recognition, an informal or formal social group within a workplace, development of affinity in workplace, motivation, and communication are the roadmap to the people's management. In the same vein, it becomes a useful tool for managing students' unrest in Universities. The relevant of the theory to crisis management was equally exemplified, coupled with the development of a theoretical model to better simplify the nexus between HRTM and crisis management.

Implication for Management: Observations were made based on the assumptions of the theory to respond to the vacuum HRTM supposed to have filled. The study conclusively recommends that; inclusive decision making, the committee system, motivation and communication should be paramount in managing the system to enable amicable relationships for better productivity, peace and relative tranquility.

Keywords: crisis management; human relations theory; people's management; Relationship.

\section{Introduction}

Educational institutions, such as public universities, are lucid miniature of micro-societies where the roles and influences of the administrators and managers can be investigated whether as an agent of development or otherwise. One of the most difficult activities of mankind all over the world is management (Sheldreke, 2000). This is so because it has to do with the use of both human and material resources to actualise the goals and objectives of the organisation, especially in an academic community that comprises intellectuals such as teaching and non-teaching staff, as well as administrators and even students whose need and aspirations as individuals are dynamic in nature. These aspirations are directed at refining the society through the social and corporate efficiency of its members and products. To this end, it is pertinent to say that the essential roles being played by university education as an apparatus of social engineering cannot be under-rated. This, therefore, requires a dynamic and humanitarian strategy.

Despite the apparent benefits of university education to nation-building, the potentials of the university system in developing countries to fulfil its responsibility is frequently obstructed by long-standing problems bedevilling the system. That is why Ekundayo and Ajayi (2009) concluded that higher education in Nigeria is in travail; the system is riddled with crises of various dimensions and magnitudes. Amongst other maladies faced by universities is student unrest of various magnitudes. Despite the efforts of government and other stakeholders to maintain relative peace and tranquillity in the management of university system, there has been an increase in unrest, ranging from trade unions and students' oriented crisis in almost all the Nigerian universities, most specifically in public universities. This was supported by the conclusion of Omodan (2016) that the 
frequent industrial actions embarked upon by various trade unions in various tertiary institutions seem to have hindered the speedy actualisation of the set predetermined goals and objectives of tertiary institutions. Even student-oriented crisis in Nigeria, South Africa and Kenya, including Western countries such as United States of America and Sri Lanka, is also not lagging behind, and this is evidenced in many relative crises that usually lead to closure of schools and boycotts of lectures by students, shooting, killing and sustenance of injuries during crises (Akeusola, Viatonu, \& Asikhia, 2012; Dube \& Hlalel, 2018; Premium Times, 2017; Virginia Commonwealth University, 2012; Weeramunda, 2008). This is to justify that student unrest is not only limited to Nigeria but other countries and continents also face the problem.

In examining the challenges of student unrest, university managers and administrators must be aware of these enormous responsibilities and be able to find a lasting solution to the problem. In place of this, one could argue that many universities are not actually meeting up with their predetermined goals and objectives, and therefore, call for the use and adoption of relevant mechanism, such as Human Relations Theory of Management (HRTM), in order to salvage the system. This is to say that this study is aiming at reconstructing the organisational management system, mostly universities, in order to effectively manage human capital for peace and tranquillity and also for productivity sake. This study, therefore, engages in a thorough explication of the HRTM with justifiable arguments towards the interrelatedness of HRTM and management of student unrest in the university system.

\section{Research question}

In order to give direction to this theoretical exploration, the following research question is raised to pilot the study:

1. How can HRTM be reconstructed to enhance people's management and students' oriented unrest in the university system?

\section{Objectives of the study}

This study aims to reposition with critical analysis of the HRTM to enhance the people's management and students' oriented crisis in the university system. That is, the quintessential of HRTM is explored, analysed and redirected to respond to the management of human capital in the university system. To achieve the aims as mentioned above, the study explores:

1. The nitty-gritty of HRTM, analyses and diagrammatically interprets the assumptions in line with how it could be used to respond to management of unrest.

2. The veracity of the HRTM using observations and the literature to justify the assumption of HRTM to management of unrest in universities.

\section{Methodology}

This study adopted observations and the literature on the student unrests in the universities in Nigeria as a research approach. This was performed to argue the lacuna created using or not using HRTM. However, the theoretical deductions, observations and the supporting literature were analysed by theoretical analysis. Theoretical analysis was described by Dix (2007) as academic research that is based on theoretical decoration, analysis and interpretation. This is not a method that is generally applied to all studies but only applicable to researchers' attitude and desires to make sense of the phenomenon about the chosen theory (Fawcett \& Downs, 1986). This approach, according to Jasso (1988), can influence design and research methodology; most notably the research that is based on a theoretical sense-making. The method under consideration, in my view, is a structured body of knowledge where the theoretical and conceptual materials are both the research process and the outcomes of the research. That is, the research process, findings and the conclusion are based on reflective arguments, experiences and belief of the researcher with reference to the theory. In order to implement theoretical analysis, I draw on the theoretical deductions, observations and the supporting literature, and subjected them to personal consensual, interpretational and social understanding for the purpose of making viable arguments. The following section discusses the presentation and the analysis of HRTM.

\section{Evolutionary development of Human Relations Theory of Management}

Human Relations Theory of Management was developed from an empirical study of Elton Mayo and his associates such as Roethlisberger, Dixon and Follett who carried out the study at the Hawthorne Plant of Western Electric near Chicago, United States between 1920s and 1930s (Ajayi \& Ayodele, 2011; Barnard, 1938). The empirical research was designed to test the effect of lighting intensity on worker productivity, and the influence of human relations on work behaviour (Mayo, 1933). This struggle in search of a suitable approach to management came as a result of the perceived inhumane holistic approach of classical approaches, such as scientific and administrative management theory. The failure of classical theories, therefore, gave birth to the human relations approach in an organisation, which came into actual existence in the 1930s as an alternative to the classical approach to organisational analysis (Hartzell, 2017). This is because the classical theorists appear to have neglected and underemphasised the importance of humanism and sociopsychological aspects of individual's behaviour as a panacea to organisational performance in the operations of the organisation (Coombs, 2007).

Human relation school of thought appears to be a developmental deviation from the scientific and classical viewpoint that man was an economic animal who responds only to financial incentives. The principles of the classicist, according to Ajayi and Ayodele (2011), tend to create more problems at the place of work rather than solving them; this is because the classicist out-rightly failed to recognise human being as an essential part of the input, process and 
output of company (Ajayi \& Ayodele, 2011). The Hawthorne studies as it is popularly known (Nwankwo, 2014; Omodan, Dube, \& Tsotetsi, 2018) consisted of several experiments, such as 'the first Relay Assembly Test Room, the second Relay Assembly Group, the Medical Splitting Group, Typewriting Group and the Bank Writing Observation Room Experiments' which holds that attitudes, relationships, feelings of belonging, interpersonal skills, participative decision-making and effective communication play a key role in the performance and effectiveness of an organisation (Lunenburg \& Ornstein, 2012; Mayo, 1933).

According to Manoj (2016), in the Hawthorne studies, it was briefly explained that both the social and psychological factors at the workplace alongside the physical conditions of the workplace determine the employees' morale and output, noneconomic rewards and sanctions significantly affect the workers' behaviour, morale and output. The study further concluded that workers are not inert or isolated, unrelated individual; they are social animals; therefore, the workers tend to form small groups such as informal organisation within the organisation. Finally, the Hawthorne studies concluded that leadership style, style of supervision, communication and participation play a central role in workers' behaviour, satisfaction and productivity (Manoj, 2016). Although it was not only Mayo and his associates who contributed to the development of human relation approach, there are many contributors whose study also influence human relations movement, such as Hurt Lewin, Jacob Moreno and Douglas McGregor. Hurt Lewin originated research called group dynamics (Lewin, Lippitt, \& White, 1939). The study assumed that a democratic group that gives members a sense of belonging and allows members to participate in decision-making actively is more productive in both personal and individual satisfaction and organisational goal achievement (Ajayi \& Ayodele, 2011; Lunenburg \& Ornstein, 2012).

Jacob Moreno also made a significant contribution to the development of human relations theory and focused on the group interpersonal relationship in a sociometric technique (Moreno, 1934). Jacob Levy Moreno came up with a term called 'sociometry' from his first long-range sociometric study that took place between 1932 and 1938 at the Girls Training School Hudson, New York. In the study, Moreno used sociometric techniques for assigning residents to their respective residential cottages (Hoffman, 2000). In the study, Moreno (1953) found that assigning residence based on sociometry significantly reduced the number of runaways from the facility. Moreno (1953) concluded that groups that comprise people with relatively similar affinity for one another will perform better than a group lacking such an effective relationship. That is, it shows how individuals associate and relate with each other when acting as a group towards a specified goal and target objectives (Moreno, 1960). This is what Borgatta (2007) expound to mean that when people are allowed to make their choice of things, actions and groups to relate with, it may effectively contribute to such individual effectiveness. Therefore, that choices of people and choices of things are one of the important elements in all active human relations (Moreno, 1953).

Like Hurt Lewin and Jacob Moreno, Douglas McGregor targeted the perspective of motivation in an organisation (Yacoub, 2016). Douglas McGregor's perspective on human relations management emanated in 1960 in his book titled 'The Human Side of Enterprise'. In the book, he proposed two theories viewing employees' motivation in two dimensions. He labelled the perspectives 'Theory $X$ and $Y$ '. The divergent perspective of the theories was premised on the management's role in managing people for the economic benefit of the firm towards production (McGregor, 1960). Theory Y assumes that people want to work, that they are responsible and self-motivated, that they want to succeed and that they understand their position in the company hierarchy (Dininni, 2017; Odionye, 2014). This is in contrary to Theory $X$, which assumes that employees are naturally lazy and unmotivated, that they seek nothing more from their jobs than security and that they require discipline from without (McGregor, 1960). In short, Dininni (2017), therefore, argued from the dichotomy of theory $\mathrm{X}$ and $\mathrm{Y}$ that human relations theory, rather than viewing the stakeholders as merely one more component in the company wheel, asserts that the organisation will prosper as it helps the employee thrive. Hence, the underlying assumptions of HRTM were born out of experiments and outcomes of the Hawthorne researchers most notably from their chief populariser who identified the importance of the human factor in organisations (Ajayi \& Ayodele, 2011; Mayo, 1933; Nikolas, 2005).

\section{Assumptions of Human Relations Theory of Management and their reflective observations}

The assumptions of the theory are as follows: the needs, such as belongingness, inclusiveness and recognition, determine workers' morale than physical conditions of work environments; informal or formal social group within workplaces such as team effort, social conformity and group loyalty determines individual and group behaviours; people develop affinity for one another in the group that comprises individual with various affinities; employees are motivated by social and psychological needs coupled with economic incentives; communication, power, manipulative influence authority devoid of autocracy are important, and therefore, should be encouraged and developed in organisation (Mayo, 1933; McGregor, 1960; Moreno, 1953).

\section{Belongingness, inclusiveness, recognition and it's reflective observations}

This is one of the assumptions of the HRTM that captures the inclusiveness of the subordinates and all organisational stakeholders into decision-making processes. This is shown in the statement from the conclusion of Hawthorne studies that organisations should ensure subordinate's sense of 
belonging through inclusiveness and recognition. This is also shown in the study of Lunenburg and Ornstein (2012) that the need to including but not limited to belongingness, inclusiveness and security is essential for worker's morale and productivity than the condition of the physical environment alone.

This assumption is categorised into three dimensions given by Stoner and Wandel (1988), which are assumptions, policies and expectations. According to them, assumptions are that people want to feel useful and relevant, people want to belong and to be recognised as individuals, and that these needs are more important than money in motivating people; policies are that the management should make subordinates useful and important, the management should keep subordinates informed and listen to their objections, and the management should allow subordinates some self-direction and self-control; expectation as part of the dimensions, as argued by them, is that when information is shared with the subordinates, and they are adequately involved in routine decisions, will satisfy their basic needs to belong, and will improve morale and reduce resistance to formal authorities.

\section{Reflective observations}

Decision-making as one of the existing crisis management strategies, according to Nwankwo (2014, p. 108), is the process of choosing amongst alternative courses of action. Hence, to be able to decide on what is appropriate action on any management matters, the managers or administrators need to know and understand not only the various alternative options that exist but also how the decision would be made, that is, whether it should be participatory or otherwise. Students' involvement in decision-making is not new phenomena but seems to be not taken seriously by the university administrators (Sinclair, 2004). The concept of giving students the right to participate in the decisionmaking process emerged as a result of student movement agitation in the 1960s and early 1970s, and more recently developed in 'student voice' initiatives in schools (Mager \& Nowak, 2012).

The United Nations convention on the rights of the children in 1989 also supported this concept by promoting the right to involve young people in decisions that affect their lives (Mitra, 2009; Rudduck \& McIntyre, 2007). Student involvement in decision-making in schools also refers to the participation of students in a collective decision-making process, dialogue between students and other relevant university administrators (Adegun \& Arogundade, 2014). This is often seen as problematic to university administrators and other decision-makers, in general, because students are viewed as youngsters, unripe, therefore lacking the requisite knowledge needed to run the affairs of a school (Mager \& Nowak, 2012). Thus, neglecting students in participating in a decision that directly or indirectly affects them has been the bone of contention because of its negative output. That is why Adegun (2003) concluded that the concerned people who are affected by the major decision of the school authority needed to be involved and carried along in decision-making to avoid conflict.

It was observed that a lack of participatory decisionmaking in universities seems to have largely contributed to the rise of students' oriented crises. This is evidenced in the 2011 students' unrest in the then University of Ado Ekiti where students went on a rampage to fight against the university policy of 'No School Fees, No Exam'. The school suffered significant damages, and students, to a large extent, also were affected. The university was shut down, and many were arrested, suspended and made to pay for the damages. Not only in Ekiti State University, many universities in South West recently went to the street to protest against what they termed obnoxious increment in school fees (Mahmud, 2013). These destructive activities are associated with seemingly obnoxious government decision and policies, the poor state of facilities on campus and increase in school fees (Omisade, 2014) in the universities such as University of Lagos, Lagos State University, Olabisi Onanbanjo University and Ago Iwoye (Premium Times, 2017).

\section{Groups and social group within workplace and its reflective observations}

Another assumption from the Hawthorne study is the encouragement of group activities, social group interrelationship within the workplace such as team effort, social conformity and group loyalty, which determines individual and group behaviours towards productivities (Mayo, 1933). Nwankwo (2014) also corroborated Hawthorne study by exemplifying that team spirit and sociological factors in the workplace have greater influence in determining individual and group behaviour in an organisation. That is, committee teamwork, social interrelationships lessen conflict between group(s), and aid social conformity and loyalty from the subordinates (Nwankwo, 2014). This is supported by the findings of Hawthorne's study that production and satisfaction increased regardless of manipulation, and that human interrelationships are important contributing factors to workers' productivity (Lunenburg \& Ornstein, 2012).

According to Dininni (2017), the Human Relations Theory has a landmark contribution to the evolution of administrative thought because its significance lies in discovering and emphasising the informal organizations, and facilitates teamwork and collaborations. However, the Human Relations Theory not only brought about a revolution in the organisational analysis but also contributed significantly to the history of administrative thought by investigating the interconnectivity between supervisory practices and employee morale with the result that supervisory practices increase employee morale and productivity. This assumption also revealed how powerful is the nature of social relations in the organisations and redirects managers more towards the interpersonal aspects of organising (Coombs, 2006). 


\section{Situational analysis}

According to Ajayi and Ayodele (2011), subgroups (committee system) within an organisation formally brought together to advise managers on a legitimate course of action on specific issues. The need for university administrators to effectively organise the human resources in the system for effective and efficient management strategies through committee system cannot be under-emphasised because it can also be seen as a device for achieving coordination of activities and sharing information amongst various departments of the school (Nwachukwu, 1988). Therefore, universities, including all levels of education, need to recognise the committee system for effective disposition of administrative duties and for the purpose of achieving school objectives (Ogbomida, Obano, \& Emmanuel, 2013). Essential committees in Nigerian universities as identified by Ibukun (1997) include finance and general-purpose committee, security committee, development and promotion committee, admission committees, student affairs committee, research grants committee and ceremony committee.

One would see from the above exploration that the committee system would lessen the frequent crises in the university system. This is supported by the observation of Ikenwe (1998) and Ogbomida et al. (2013) that committee system in institutional governance ordinarily aimed at promoting democratisation of administrative process and acted as catalysts that fast track the physical and intellectual growth of the system in a competitive world. This is an indication that various committees in universities are meant to serve as an advisory body: the think-tank offers relevant and useful advice on any issues or insurgences in schools including suggestions to the Governing Councils on how to manage every threat from all quarters that could lead to crises in the system. The incidences of violence against students by faceless individuals and incessant kidnapping and abduction of both staff and students have been on the rise because of the perceived lack of effective committee system (Ogbomida et al., 2013).

\section{Motivation by social, psychological and economic incentives and its reflective observations}

Another assumption is born out of motivation, and this is obvious in the recommendation of Hawthorne's study that social and psychological needs alongside economic incentives motivate employees for better productivities (Mayo, 1933). This was supported by McGregor (1960) that the human relations concept did not go far from addressing people's needs, satisfactions and strategies to accommodate those needs for better productivity. This is why Wziątek-Staśko (2015) concluded that non-recognition and non-appreciation of subordinates in the human resource management process might significantly reduce the effectiveness of managing the entire system because the needs for subordinates and other stakeholders cannot be ignored.
In a dynamic organisation, managers are expected to create an atmosphere with which an employee will feel trusted and empowered to participate in the decisions-making process, by so doing, will enhance employee's motivation level and organisational performance. That is why Smith and Rupp (2003) concluded that performance is the result of individual motivation and resistance to change. This was also supported by the conclusion of Luthans and Stajkovic (1999) that the advancement of rewards, monetary incentives and organisational behaviour, to a large extent, contribute to individual and corporate performance. Therefore, determining and understanding the factors of employees' motivation in the organisation are largely dependent on the satisfied and motivated workforce, because motivation influences even managers' effectiveness (Analoui, 2007).

\section{Reflective observations}

All organisations, including educational organisation, always want to be successful; therefore, organisations irrespective of size and location strive to retain the best human recourses, acknowledging their critical role and influence on organisational effectiveness are not negotiable. To overcome these inevitable challenges, university management should create a healthy and positive motivational relationship within its students and other employees, and direct them towards task fulfilment (Ferlazzo, 2015). When students feel more motivated to learn, they perform better academically and lessen their urge to agitate, improve classroom behaviour and gain a higher sense of self-esteem (Nwankwo, 2014). Unfortunately, data and the direct experience of many educators show that lack of motivation affects many of our students and appears to increase their cynical urge for actions (Ferlazzo, 2015).

That is why Nwankwo (2014) described students' motivation as the act of creating the drive or energy that propels a student to specifically positive actions that lead to his or her advancement and progress within and outside the institution. A student who is admitted to a university programme may get frustrated and even drop out of school as a result of numerous de-motivating factors, such as fear of examination, fear of unfriendly lecturers and administrative staff, fear of uncanny comparisons, unfriendly infrastructures amongst others, either from the school management or from the students themselves. Therefore, interest and motivation are correlatively synonymous. Individuals with a strong interest in a specific area are intrinsically motivated to succeed in that area of endeavour because individual interest tends to be stable and long-lasting (Girmus, 2011). From the author's observation and experience in numerous student unrests, however, it is evident that university authorities pose less or no recognition to these students' motivating strategies, which, in turn, could lead to student unrest. This was supported by Dobre (2013) that a few organisations consider the human capital as being their main asset, capable of leading them to success or if not motivated properly. Thus, it is better to plan how to prevent crises than to manage it when it happens (Ekundayo, 2012). 


\section{Communication as power of manipulative influence and its reflective observations}

Communication, as one of the assumptions, also plays a central role in subordinate's behaviour, satisfaction and productivity. This is why it was recommended that communication channels between various levels in the organisation should be developed (Mayo, 1933; Roethlisberger \& Dickson, 1939). That is why HRTM is frequently used to describe the way in which managers interact with their subordinates because this theory places great emphasis on information sharing and the involvement of subordinates in decision-making and the importance of intergroup cooperation (Stoner \& Wandel, 1988). The implication of this theory, as affirmed by Odionye (2014), is that the more frequent the interaction between any two groups, the higher the tendency to co-operate with each other. This theory is also linked to Chester Barnard's study of 1938 titled 'the functions of the executive', which argued for a 'human-based system of organization', that is, the potential of every worker and the centrality of communication to the organising process (Barnard, 1938). He drew attention away from formal organisational structures towards communication, cooperation and the informal organisation, and the result of the studies regarding human relations in the workplace shows that people want to have a sense of belonging and significance whilst being treated with value and respect (Mayor, 1930).

As argued by the author, this assumption believed that if management showed more concern for its employees, their satisfaction would increase relative peace and organisational productivity (Mayor, 1930). However, even if we might say that the theorist under HRTM inherited trends from classical and scientific development, their theorisation and focus are more centred on human needs and qualities, and not on technology that dictated the optimal organisational forms of classicist (Onday, 2016). In other words, it was on their motive to manage organisations from a human and humane point of view, as against the technological imperativeness of classicist.

\section{Reflective observations}

Communication in the university system is the ability of school management to convey or share ideas and feelings effectively to the staff and students with information being understood; otherwise, communication has not taken place. Communication is seen as one of the factors that contribute to the success of any organisation because meaningful communication informs and educates people in the organisation at all levels and motivates them to support the strategy and mission set-out (Barrett, 2002). Although there are certain barriers for effective communication that has become inevitable for the university administrators to encounter, such as poor communication planning, conflict of interest, distrust of source, faulty translation, personal feelings and feelings of personal insecurity (Ajayi \& Ayodele, 2012), these barriers make it complex, difficult and frustrating to achieve the aims and objectives with which communication intend to achieve (Kolawole, 2017; Nwankwo, 2014).

Often there have been disharmony and various crises amongst the stakeholders in most Nigerian universities over communication gaps between the top (school management) and bottom (students), where mostly the students feel left out or kept in the dark from various happenings in the school. The aftermath of the rifts has always been unrest, and therefore, poses a negative implication on general productivity. In universities of Nigeria, it appears that there are dissatisfactions amongst the students with the way the university administrators handle their communication system. During my encounter with the students' leaders of Ladoke Akintola University, Ogbomoso, I perceived that the real information about the positions of management on the then closure of the school as a result of the staff unpaid salary is not well disposed or I instead say the administrators have been political with the situation. This situation alone has led the students to embark on both peaceful and radical protest several times from 2017 to 2019.

It appears that the perceived high level of students' crisis in public universities by the students may not be unconnected with the way the school managers are managing their strategic mean of disseminating information from the top management to the entire stakeholders in the system. Therefore, for any organisation that is working towards actualising its goals and objectives, the handler of information communication, communication planners and administrators must be up and doing with upward innovation and strategic thinking towards ensuring the actualisation of organisational goals. Maybe that is why Nwankwo (2014) concluded that people need the information to do their jobs or to take action. In other words, each person or group in an enterprise needs information to coordinate activities with others.

\section{The implication of Human Relations Theory of Management to university practice and crisis management}

The theory views human beings as individuals with differing psychological motivations, distinct and dynamic behaviour affecting performances. That is why Oraemes (1997) emphasised that humanly treating students have an impact on the educational administration in several ways, which include the increasing effort to democratising the practise of educational administration. Undie (2001) believed that advocates of democratic administrator should take steps to satisfy both motivational and psychological needs of university stakeholders, including students for better productivity. The implication of this theory, as affirmed by Odionye (2014), is that the more frequent the interaction between any two groups, the higher the tendency to cooperate with each other. 
The Human Relations School of thought, which accentuated that treating students and employees in a human way, will have a significant influence on general administration in school system, is related to the recommendation of Kimbrough and Nunnery (1983) and Oraemes (1997) that HRTM increases effort to democratise the practise of educational administration, most especially in tertiary institutions. Likewise, it also laid emphasis on the responsibility of university administrators on the promotion of relationships between members of the organisation because harmony and high staff morale, according to Kimbrough and Nunnery (1983), were considered essential factors for improved organisational peace. Meanwhile, this movement also presupposes an implementable strategy of dealing with both academic and non-academic staff, as well as students as a psychological being (Michael, 2011).

As human resources in university organisation comprised of the students, lecturers, administrative staff and school authorities, the approach of human relations in university means a practical investment in human resource with the right to participate in the determination of school goals and policies and to exercise professional judgement about what to do and how to empower the school environment (Kulsreshtha, Patel, \& Singh, 2016). Human relation in the universities, therefore, means the ability of all stakeholders to be able to judge what and how to perform things and develop a harmonious relationship within the school environment. Thus, the human relation is like a power given to people in universities to participate in the determination of school and educational goals and to exercise their judgements of what, why, how, when and where to perform things for the purpose of developing harmonious relationship within the school environment (Kulsreshtha et al., 2016). This supported the report of Singh (2000) that a peaceful school environment is the result of the harmonious relationship amongst the workforce.

This theory is, therefore, unequivocally relevant to this article because of its trend towards power equalisation, reduction in the power and status differential between authorities and the subordinates (Sridhar, 2014). It also exemplified the importance of effective communication as a panacea to smooth university operations, and it equally helps to explain why the university administrators should recognise various communication tools in order to ensure effective co-operation with inclusion and involvement of stakeholders in decisionmaking (Odionye, 2014). If the students and their leaders including other staff are recognised with adequate participation in decision-making, most especially the issues that directly or indirectly concern their welfare, this will instil into them how significant they are to the development of the system (Omodan et al., 2018). This psychological and situational motivation will, in turn, change students' behaviour and other relevant to act responsibly, thereby ensuring a peaceful environment devoid of crises.

\section{Theoretical model to justify the nexus between Human Relations Theory of Management and crisis management}

The following theoretical model (Figure 1) formulated by the researcher in line with the assumptions/principles of HRTM will open more understanding of the relationship between this theory and the impetus of crises management in the university system.

The above-developed theoretical model indicates the process and practices in the university system, which leads to individual well-being, university effectiveness, societal wellbeing, and relative peace and tranquillity. The inputs involve the stakeholders, such as administrators, employee's groups, students and students' unions, and government. Based on the above theory, it is assumed that situational inputs, such as decision-making, committee system, communication, dialogue and motivation, are stimuli to mutual relationships between all the organisational stakeholders. In the case of university system, which is the hallmark of this study, it is expedient of the university administrator to recognise all the situational input, because by so doing, it leads to concrete and outright recognition of human relation policies and assumptions, that is, making subordinate useful and important, keeping subordinates informed, listen to objections, as well as allowing subordinates' self-direction and self-control. This is in support of the opinion of David (2013) and Undie (2001) that a democratic system satisfies both the motivational and psychological needs of university stakeholders for better productivity.

Furthermore, when the obligation of human relation policy and assumptions are met, it leads to the commitment of all relevant stakeholders, they experience some self-competence and self-esteem, and they also feel satisfied and important. All these stimulate morals and reduce the spirit of resistance to some likely unpleasant issues. This is in consonance with the highlighted implication of Maslow theory of motivation by Lunenburg and Ornstein (2012) that outstanding schools require leaders who have the ability to motivate people for self-reliance and self-actualisation, and to maximise their performance to grow professionally. To achieve this, university management/authorities are expected to know and be able to apply the basic postulations from this model.

The resultant effect of this process is, therefore, the achievement of university goals and objectives, part of which are individual well-being, university effectiveness and process efficiency, societal well-being and above all, peace and tranquility, which stand as an output for this model. This showed that for university goals to be achieved, all apparatus of inter- and intra-relationships must be put in place to ensure unhindered processes. The overall management of all stakeholders, including students, will lead to the desired peace, harmonious relationships and development of university education, in general. This is in line with the recommendation of Etadon (2013) that there should be a 


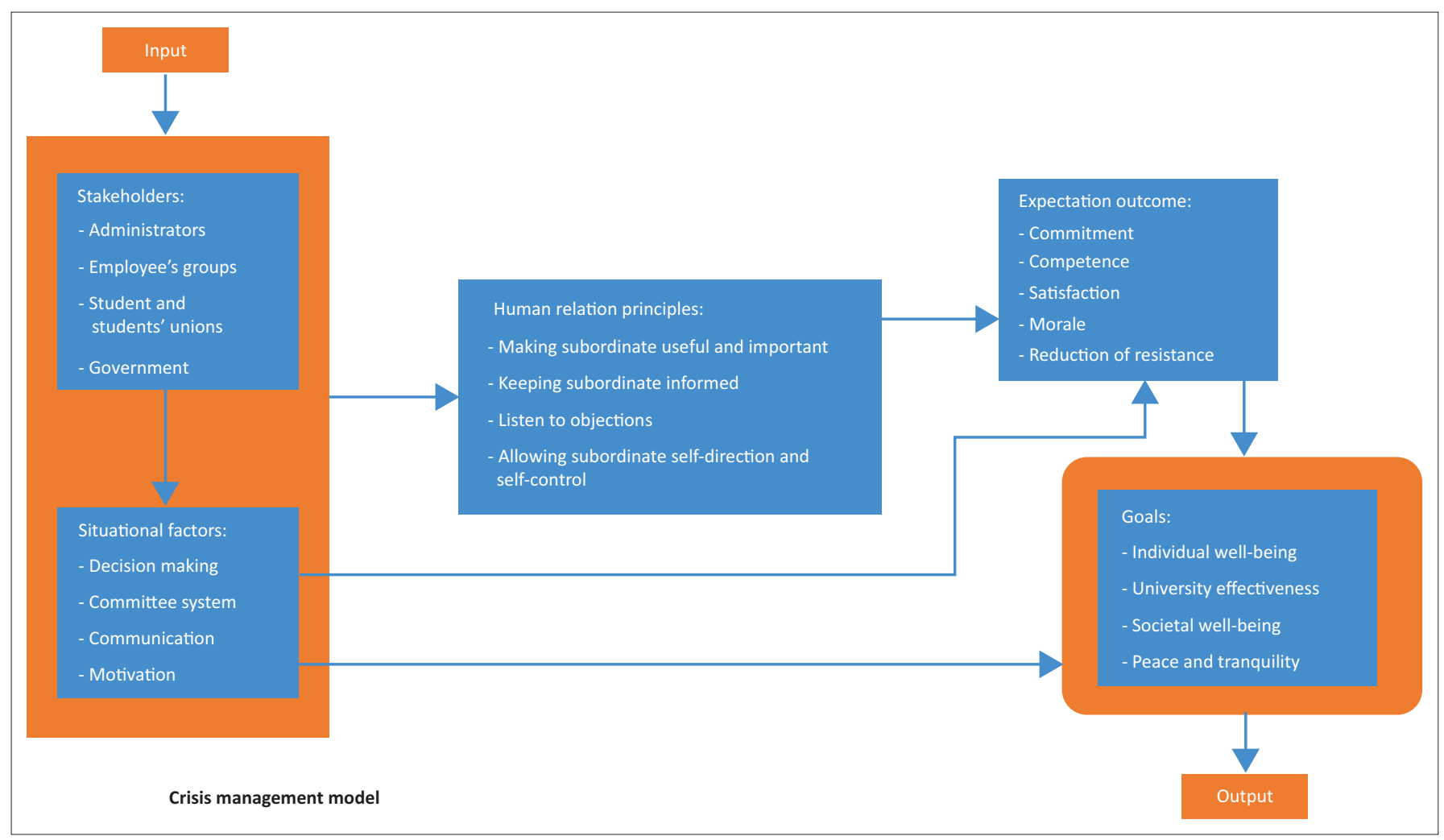

FIGURE 1: Crisis management model.

considerable improvement in the living and working environment of universities generally.

\section{Conclusion and recommendations}

As universities are recognised as an ivory tower of knowledge consisting of many scholars, including students with various belief and wants, an organisational crisis is inevitable, but the ability of the school management to control and manage it makes them effective. Therefore, every organisation should gear its devotion to crisis management. When the authority of these universities are people's oriented and base their style of leadership on subordinates, such as students and staff; convey the decisions and policies of the management to the staff and students, form inclusive governance comprising all stakeholders, make use of committee system to solving issues, engage student in dialogue, ensure student motivation as well as provision of students personnel services. This, in turn, may ensure the harmonious relationships between these parties towards achieving the goals and objectives of the university system.

Finally, as the word management, according to Ajayi and Ayodele (2011), practically means getting things done, utilising both human and material recourses. The system is needed to be reconstructed where the managers and administrators in universities take cognisance of the above assumptions of HRTM. This is expedient because university management and administration are centred on the performance of executive duties, such as policy formulation and implementation, decision-making, controlling of the activities of the organisation amongst others for the overall achievement and most importantly to maintain peace and orderliness in the system. Hence, there must be a careful arrangement and systematic use of both human and material resources, situations and opportunities for the achievement of the specified objectives in the system (Nwankwo, 2014). Based on the above analysis exposed from the postulations of HRTM, the following recommendations were made, and if these recommendations are strictly adhered to, this will enhance the management of people and crisis in university system for better productivity:

1. Inclusive Decision-Making: As participatory decisionmaking is argued and confirmed to be productive in managing the affairs of any organisation, it is hereby recommended that university manager and administrators should at all-time recognise the importance of other stakeholders in the process of decision-making most importantly in the matter and issues that concern them. Recognising their importance is not enough but making their inputs and opinions counts is also necessary because this theory places great emphasis on the involvement of subordinate in decision-making the importance of intergroup co-operation Stoner and Wandel (1988) likewise. This was also supported by Oraemes (1997) that proper recognition of HRTM enables the democratisation of educational institutions, most especially in tertiary institutions.

2. Committee System: As the university system is not different from other organisations based on its organograms and departmentalisation, unit and sub-units, 
it is expected from the authorities of the system to adopt the use of committee system, as this will enable efficient and effective utilisation of human resources and also enhance the spirit of delegation of power between the super-ordinates and the subordinates. This is recommended because the predominant function of committees in organisations, according to Ajayi and Ayodele (2011), is to advise managers on a legitimate course of action on specific issues. Therefore, there is a need for universities administrators to effectively organise the human resources, including students, for effective and efficient management through committee system because it is a device for achieving coordination of activities amongst various departments of the universities (Nwachukwu, 1988).

3. Motivation: Motivation is one of the keys that drive human resources in any organisation, and if this phenomenon is adequately recognised and implemented in any organisation would go a long way in achieving the aims and objective of the organisation and also ensure meeting the needs of the stakeholders. It is evident that if employees are motivated by social and psychological needs coupled with economic incentives. This, according to Nwankwo (2014), will lessen conflict potentials, and aid social conformity and loyalty of people to the organisation. Therefore, university authorities should always ensure that the needs of all stakeholders, including students, such as belongingness, recognition, physical conditions of work environments and security, are met because it goes a long way in determining individual morale.

4. Communication: Communication is the lifeline of any organisation; this is so because good and unambiguous dissemination of information in organisation solidify mutual relationships amongst the stakeholders. This is why Barrett (2002) opined that communication is one of the strongest factors that contribute to the success of any organization because it informs, motivates and educates people in the organisation at all levels to support the strategy and mission set-out. University authorities should, therefore, ensure the use of various communication tools to ensure effective and efficient dissemination and utilisation of information. This is in support of Odionye (2014) that university administrators should recognise various communication tools to ensure effective co-operation amongst stakeholders in the university system.

\section{Acknowledgements Competing interests}

The authors have declared that no competing interest exists.

\section{Authors' contributions}

B.I.O. is the principal researcher, C.T.T. is the supervisor, whilst B.D. is the co-supervisor. The article is an extract from $\mathrm{PhD}$ thesis. All authors made huge contributions.

\section{Ethical consideration}

This study is a part of a more extensive research study with ethical approval number UFS-HSD2018/1105 under the ethics committee of the University of the Free State, South Africa.

\section{Funding information}

This research received no specific grant from any funding agency in the public, commercial or not-for-profit sectors.

\section{Data availability statement}

Data sharing is not applicable to this article as no new data were created or analysed in this study.

\section{Disclaimer}

The views and opinions expressed in this article are those of the authors and do not necessarily reflect the official policy or position of any affiliated agency of the authors.

\section{References}

Adegun, O.A. (2003). Sociology of education. Ado-Ekiti: Petoa Educational Publisher.

Adegun, O.A., \& Arogundade, B.B. (2014). Students' participation in governance and organizational effectiveness in universities in Nigeria. Mediterranean Journal of Social Sciences, 5(9), 2039-2117.

Ajayi, I.A., \& Ayodele, J.B. (2011). Fundamentals of educational management. Ado Ekiti: Green Line Publisher.

Ajayi I.A. \& Ayodele J.B. (2012). Fundamentals of Educational Management. Ado Ekiti: Green Line Publisher

Akeusola, O., Viatonu, O., \& Asikhia, O.A. (2012). Perceived causes and control of students' crises in higher institutions in Lagos State, Nigeria. Journal of Education and Practice, 3(10), 60-68.

Analoui, F. (2007). Strategic human resource management. Strategic Human Resource Management. London: Thomson.

Barnard, C.I. (1938). The function of an executive. Cambridge, MA: Harvard University Press.

Barrett, D.J. (2002), Change communication: using strategic employee communication to facilitate major change. Corporate Communications: An International Journal, 7(4), 219-231. https://doi.org/10.1108/13563280210449804

Borgatta, E.F. (2007). Jacob L. Moreno and sociometry: A mid-century reminiscence. Social Psychology Quarterly, 70(4), 330-332. https://doi.org/10.1177/ 019027250707000404

Coombs, W.T. (2006). The protective powers of crisis response strategies: Managing reputational assets during a crisis. Journal of Promotion Management, 12(3/4), 241-260. https://doi.org/10.1300/J057v12n03_13

Coombs, W.T. (2007). Ongoing crisis communication: Planning, managing and responding (2nd ed.). London: Sage Publications Ltd.

David, A. (2013). Students' Crisis in Nigerian Tertiary Educational Institutions: A Review of the Causes and Management Style. Khazar Journal of Humanities \& Social Sciences, 16(1), 56-76.

Dininni, J. (2017). Human relations management theory. Retrieved from https://www. business.com/articles/human-relations-management-theory/july/2017

Dix, A. (2007). Theoretical analysis and theory creation. Retrieved from https://pdfs. semanticscholar.org/d906/508247719b7c67af70ac13b88ec7a9d87203.pdf

Dobre, O. (2013). Employee motivation and organizational performance. Review of Applied Socio-Economic Research, 5(1), 53-60.

Dube, B., \& Hlalele, D. (2018). Engaging critical emancipatory research as an alternative to mitigate school violence in South Africa. Educational Research for Social Change, 7(2), 74-86. https://doi.org/10.17159/2221-4070/2018/ v7i2a5

Etadon F.I. (2013). Campus Conflict Involving Students and University Management in Nigeria: A Case Study of the University of Ibadan. International Journal of Education Science, 5(3), 333-343.

Ekundayo, H.T. (2012). Towards strengthening the relationship between trade unions and university management in Nigeria. African Research Review: An International Multidisciplinary Journal. Ethiopia, 6(2), 266-273. https://doi.org/10.4314/afrrev. v6i2.24

Ekundayo, H.T., \& Ajayi, I.A. (2009). Towards effective management of university education in Nigeria. International NGO Journal, 4(8), 342-347.

Fawcett, J., \& Downs, F. (1986). The relationship of theory and research. Norwalk, CT: Appleton Century Crofts. 
Ferdous, J. (2016). Organization theories: From classical perspective. International Journal of Business, Economics and Law, 9(2), 1-6.

Ferlazzo, L. (2015). Creating the conditions for student motivation, student engagement, 19 March. Retrieved from http://www.edutopia.org/blog/creatingconditions-for-student-motivationlarry-ferlazzo

Girmus, R.L. (2011). How to motivate your students. In New Mexico State UniversityGrants Round-Up Conference, September 30-October 1, 2011, Grants, NM.

Hartzell, S. (2017). Neoclassical theory of management: The human relations approach. Study.come. Retrieved from https://study.com/academy/lesson/neoclassical-theory-of-management-the-human-relations-approach.html\# transcriptHeader

Hoffman, C. (2000). Introduction to sociometry. sociometry_intro_original.docx. Retrieved from http://www.hoopandtree.org/cons_sociometry_introduction.pdf

Ibukun, W.O. (1997). Educational management: theory and practice. Ado-Ekiti: Green Line Publishers.

Ikenwe, E. (1998). The use of committees in higher institutions in Bendel state (Unpublished thesis). University of Nigeria, Nsukka.

Indabawa, S.L., \& Uba, H. (2014). Human relations and behavioral science approach to motivation in selected business organizations in Kano Metropolis Nigeria. European Journal of Business and Management, 6(25), 168-174.

Jasso, G. (1988). Principles of theoretical analysis author(s). Sociological Theory, 6(1) 1-2. https://doi.org/10.2307/201910

Kimbrough, R.B., \& Nunnery, M.Y. (1983). Educational administration. An introduction. New York, NY: Macmillan Publishing Co. Inc.

Kolawole, A.O. (2017). Organisational pressure and communication as determinates of quality of worklife of women in tertiary institutions in south west Nigeria (Ph.D thesis). Ekiti State University, Ado Ekiti.

Kulsreshtha, A.K., Patel, J.S., \& Singh, H. (2016). A study of the effect of human relations in school organization. Retrieved from https://pdfs.semanticscholar. org/8e82/b5827fc6d02a7cd8b9035eb81b4001ca3180.pdf

Lewin, K., Lippitt, R., \& White, R. (1939). Pattern of aggressive behavior in experimentally created social climates. Journal of Social Psychology, 10(2), 271-299. https://doi.org/10.1080/00224545.1939.9713366

Lunenburg, F.C., \& Ornstein, A.C. (2012). Educational administration: Concept and practices (6th ed.). New York: Linda Schreiber-Ganster.

Luthans, F., \& Stajkovic, A.D. (1999). Reinforce for performance: The need to go beyond pay and even rewards. The Academy of Management Executive, 13(2), 49-57. https://doi.org/10.5465/ame.1999.1899548

Mager, U., \& Nowak, P. (2012). Effects of student participation in decision making at school. A systematic review and synthesis of empirical research, Educationa Research Review, 7(12), 38-61. https://doi.org/10.1016/j.edurev.2011.11.001

Mahmud, A. (2013). Abdul Mahmud: The June 12, 1993 struggles: A personal account The Scoop. Retrieved from http://www.thescoopng.com/2013/06/12/abdulmahmud-the-june-12-1993-struggles-a-personal-account/

Manoj, K.B.A. (2016). Human relations theory (Elton Mayo). Retrieved from https:// polticsmania.files.wordpress.com/2016/10/human-relation-theory-elton-mayo. pdf

Mayo, E. (1933). The human problem of an industrial civilization. New York, NY: Macmillan.

Mayor, E. (1930). Motivation within an innovative work environment: An ARM case study. Retrieved from http://businesscasestudies.co.uk/arn

McGregor, D. (1960). The human side of enterprise. New York, NY: McGraw-Hill.

Michael, P. (2011). Human relations. Retrieved from http://www.witipedia.com

Mitra, D.L. (2009). Strengthening student voice initiatives in high schools: An examination of the supports needed for school-based youth-adult partnerships. Youth and Society, 40(3), 311-335. https://doi.org/10.1177/0044118X08316211

Moreno, J.L. (1934). Who Shall Survive? Beacon, New York, NY: Beacon House.

Moreno, J.L. (1953). Who shall survive? (Rev. ed.). New York, NY: Beacon House.

Moreno, J.L. (1960). The sociometry reader. Glencoe, IL: The Free Press.

Nikolas, R. (2005). Human relations theory and people management. Retrieved from https://www.corwin.com/sites/default/files/upm-binaries/9805 039184ch02.pdf
Nwachukwu, C.C. (1988). Management, theory and practice. Onitsha: Africana Feb Publishers Limted.

Nwankwo, J.I. (2014). Management in education: Modern approaches in educational management. Ibadan: Giraffe Books.

Odionye, C.M. (2014). Evaluation of crisis management strategies in selected universities in south-east Nigeria (M.A dissertation). University of Nigeria, Nsukka.

Ogbomida, A.H., Obano, E.J., \& Emmanuel, O.O. (2013). Utilization of committee system in the administration of Nigerian universities. Academic Research International, 4(4), 392-399.

Omisade, T. (2014). OAU shut indefinitely after protests over increase in school fees. Daily Post. Retrieved from http://dailypost.ng/2014/06/19/oau-shut-indefinitelyprotests-increase-school-fees/

Omodan, B.I. (2016). Influence of trade unionism on management of tertiary institutions in Ekiti State (M.Ed. thesis). Ekiti State University, Ado Ekiti.

Omodan, B.I., Dube, B., \& Tsotetsi, C.T. (2018). Collaborative governance and crisis management in Nigerian universities: An exploration of students' activism. In M.M. Dichaba \& M.A.O. Sotayo (Eds.), Rethinking teaching and learning in the 21st century (pp. 48-68). Pretoria: African Academic Research Forum.

Onday, O. (2016). Human resource theory: From Hawthorne experiments of Mayo to groupthink of Janis. Global Journal of Human Resource Management, 4(1), to group -110 .

Oraemes, J.C. (1997). Introduction to politics of education. Port Harcourt: Bengray.

Premium Times. (2017). University of Ibadan suspends student union leaders. May 30 2017.

Roethlisberger, F.J. \& Dickson, W.J. (1939). Management and the Worker. Pp. xxiv, 615 Cambridge, Mass.: Harvard University Press. https://doi.org/10.1177/00027 1624020800170

Rudduck, J., \& McIntyre, D. (2007). Improving learning through consulting pupils. New York, NY: Routledge.

Sheldrake, R. (2000), "The "sense of being stared at" does not depend on known sensory clues', Biology Forum, 93, 209-24.

Sinclair, R. (2004). Participation in practice: Making it meaningful, effective and sustainable. Children and Society, 18(2), 106-118. https://doi.org/10.1002/ chi.817

Singh, J. (2000). Performance productivity and quality of frontline employees in service organizations. Journal of Marketing, 64(4), 15-34. https://doi. org/10.1509/jmkg.64.2.15.17998

Smith, A.D., \& Rupp, W.T. (2003). An examination of emerging strategy and sales performance: Motivation, chaotic change and organizational structure. Marketing Intelligence and Planning, 21(3), 156-167. https://doi.org/10.1108/0263450 0310474

Sridhar, M.S. (2014). Schools of management thought. Indian Space Research Organization. Retrieved from https://www.researchgate.net/publication/224952289

Stoner, A.F., \& Wandel, C. (1988). Management (3rd ed.). New jersey: Prentice Hall.

Taylor, F.W. (1911/1947). Principles of scientific management. New York, NY: Harper and Row Publisher Inc. (Taylor's ideas first come up in Principles of Scientific Management. In 1911).

Undie, J. 2001. Educational Governance. Calabar: Tabson.

Virginia Commonwealth University. (2012). Threat assessment and violence prevention. Policy Statement and Purpose, Virginia Commonwealth University. Retrieved from https://policy.vcu.edu/sites/default/files/Threat $\% 20$ Assessment $\%$ 20and $\% 20$ Violence $\% 20$ Prevention.pdf

Weeramunda, A.J. (2008). Socio political impact of student violence and indiscipline in universities and tertiary education institutes. Research Studies on Tertiary Education Sector. National Education Commission Sri Lanka.

Wziątek-Staśko, A. (2015). Effective factors in enhancing managers' job motivationcross-cultural context. Management International Conference, Portoroz, Slovenia. 28-30 May, 2015.

Yacoub, M. (2016). The influence of classical and human relations approaches in management today, a critical evaluation. Management Theories and Philosophies Module: University of South Wales. Retrieved from https://www.researchgate. net/publication/311949526 